DOI

\title{
ТЕОРЕТИКО-МЕТОДОЛОГІЧНІ ПІДХОДИ ДО ОЦІНЮВАННЯ ЯКОСТІ ВИЩОЇ ОСВІТИ В КОНТЕКСТІ СВІТОВИХ РЕЙТИНГІВ ВИЩИХ НАВЧАЛЬНИХ ЗАКЛАДІВ
}

\author{
(c) А. В. Кайдалова, О. В. Посилкіна \\ Національний фрармацевтичний університет, Харків
}

\begin{abstract}
Резюме: у статті розглянуто світові рейтинги вищих навчальних закладів; принципи та методологію побудови рейтингів, їх основні індикатори, показники ранжування вищих навчальних закладів та їх роль в оцінюванні якості освіти.
\end{abstract}

Ключові слова: якість освіти, світові рейтинги вищих навчальних закладів, індикаторні показники у визначенні рейтингів, критерії оцінювання рівня якості.

Вступ. Зміни, пов'язані з інтеграційними процесами, з визнанням дипломів випускників, зумовлюють забезпечення та контроль якості вищої освіти, рейтингування та моніторингу діяльності медичних та фрармацевтичних ВНЗ.

Питання участі вітчизняних навчальних закладів, в тому числі медичних та фармацевтичних, у світових рейтингах розглядається як серйозна проблема протягом останніх років, що досить широко обговорюється в Україні.

На сучасному етапі розвитку вищої освіти рейтинги ВНЗ виступають не лише як засоби забезпечення конкурентоспроможності, а й як інструменти забезпечення якості вищої освіти. Для формування національної системи рейтингування ВН3, зокрема медичного та фрармацевтичного профілю, важливим $€$ аналіз міжнародного досвіду побудови різних рейтингів.

У системі забезпечення та оцінювання якості освіти важливе значення має внутрішній та зовнішній моніторинг у діяльності ВНЗ. Якщо внутрішній моніторинг - це оцінка власне ВНЗ своєї діяльності, то зовнішній моніторинг - це оцінка якості освіти державою, суспільством та освітнім середовищем.

Проблеми оцінювання якості вітчизняної вищої освіти та її інтеграція у світовий простір розглянуто в роботах Б. С. Зіменковського, А. В. Ковальова, Ю. М. Колесника, В.М.Компанієць, Ю. М. Нерянова, Н. І. Трішкіної та ін. [4-6, 11].

Роль рейтингування як механізму оцінювання якості освіти розглянуто у наукових працях Л. П. Валенкевича, М. Р. Гжегоцького, О. Г. Дубінського, М. З. Згуровського, Р. Б. Лесика, М.В.Михайличенко, Л. І. Остапюк, І. І. Солонинко, О. В. Фінкільштейна, О. П. Яворовського та ін. [1-3, 7-9].

Незважаючи на освітні рефрорми, в яких набувають велике значення системи моніторингу якості та рейтингування ВН3, всебічний і комплексний характер досліджень, представлених у названих наукових працях, потребують досліджень, зокрема питання впливу рейтингів ВНЗ на процеси надання освітніх послуг та забезпечення якості вищої освіти.

Метою статті $€$ аналіз методології фрормування світових рейтингів ВН3, визначення основних принципів та індикаторів ранжування, вивчення специфріки зовнішньої оцінки якості освіти для посилення міжнародного рівня вітчизняних медичних та фрармацевтичних ВН3, що здійснюють підготовку майбутніх фрахівців фрармації.

Результати й обговорення. Аналіз зарубіжного досвіду висвітлив, що процеси становлення, розвитку та вдосконалення світових освітніх систем на міжнародному рівні розвивалися різними шляхами. Зокрема, європейські країні першими почали активізувати проблеми якості навчання, проводити пошук методів їх вирішення та формування системи якості освіти.

У наукових джерелах наголошується, що європейські системи якості освіти базуються на стандартах і рекомендаціях, принципами яких $\epsilon$ : зацікавленість студентів і роботодавців у якості освіти, автономії закладів, внутрішнє та зовнішнє забезпечення якості освітніх послуг [3, 5, 11].

Слід зазначити, що історія світових рейтингів ВНЗ до 80-х років була відсутня. Це було пов'язано з відсутністю конкуренції як на внутрішньому, так і на зовнішньому освітньому просторі.

Першим кроком у проведенні зовнішньої оцінки діяльності ВН3 стала публікація журналом US News \& World Report у 1983 році першого у світі рейтингу університетів, який започаткував процеси глобалізації вищої освіти. Головною метою цього рейтингу було надання інфрормації для абітурієнтів.

Згодом з розвитку конкуренції університетів у боротьбі за абітурієнтів, зокрема іноземних, для забез-

ISSN 2312-0967. Pharmaceutical review. 2015. № 4 
печення належного рівня якості підготовки фахівців, отримання грантів та фрінансування освітніх програм, рейтинги стали набувати все більшої значущості. Так, рейтинги, які були опубліковані у 80-90-хх роках, сорормували методичні підходи до незалежної оцінки якості ВН3, а саме до оцінки педагогічної та наукової діяльності ВН3 [17].

В аспекті досліджуваної проблеми встановлено, що на сьогодні налічується понад 50 національних та понад 10 міжнародних рейтингів для оцінки діяльності ВН3 $[1,8]$. Метою рейтингів $€$ визначення кращих ВН3 світу та оцінка їх діяльності, але кожен рейтинг передбачає використання своїх показників для визначення конкурентного потенціалу ВНЗ.

У ході наших досліджень було проаналізовано найбільш відомі та всесвітньо визнані світові системи моніторингу та рейтингування ВНЗ та складено хронологію розвитку світових рейтингів та узагальнено їх основні кількісні характеристики (табл. 1).

Необхідно констатувати, що серед визнаних в світовому освітньому просторі рейтингів, до впливових міжнародних рейтингів відносять ARWU (Academic Ranking of World Universities), рейтинги світових університетів QS («QS World University Rankings» i «THE» (Times Higher Education World University Rankings).

Також слід відзначити ефективність та значимість існування таких міжнародних рейтингів, як: вебометричний рейтинг «Webometrics» (Webometrics Ranking of World Universities); вебометричний рейтинг університетів світу «4ICU» (4 International Colleges
\& Universities); рейтинг ефективності наукових робіт світових університетів «PRSPWU» (Performance Ranking of Scientific Papers for World Universities); Лейденский рейтинг «CWTS»; рейтинг екологічності BH3 «UI Green Metric» (UI Green Metric Ranking of World Universities); рейтинг університетів за академічними показниками «URAP» (University Ranking by Academic Performance); всесвітній рейтинг університетів «CWUR» (Center for World Universities Rankings); міжнародний рейтинг якості викладання RUR Rankings (Round University Ranking); міжнародний професійний рейтинг університетів «GWC» (Global World Communicator); рейтинг кращих європейських університетів «U-Multirank»; світовий рейтинг науково-дослідних організацій «SCImago Institutions» (SCImago Institutions Rankings) та ін [12-25].

У контексті дослідження детально проаналізовано методологію міжнародних рейтингів ВН3, принципів ранжування та вагомість їх індикаторів.

За результатами аналізу офріційних джерел [12-25] встановлено, що світові рейтинги університетів мають як загальні тенденції, так і суттєві відмінності. Спільними є принципи побудови рейтингів - врахування різних показників 3 подальшим їх угрупуванням з урахуванням коефіцієнтів вагомості, які визначаються у кожному рейтингу індивідуально, а також принципи ранжування ВНЗ без врахування профрілю їх наукової та навчальної діяльності.

Як показав проведений аналіз, в основному міжнародними рейтингами займаються незалежні агентства, які не входять до складу Міністерств освіти чи

Таблиця 1. Світові рейтинги ВНЗ та їх загальні характеристики

\begin{tabular}{|c|c|c|c|c|c|c|}
\hline № & Назва рейтингу & $\begin{array}{c}\text { Країни-засновники } \\
\text { рейтингу }\end{array}$ & $\begin{array}{c}\text { Рік } \\
\text { запровадження }\end{array}$ & $\begin{array}{c}\text { Кільксть ВН3 } \\
\text { учасників } \\
\text { рейтингу }\end{array}$ & $\begin{array}{c}\text { Кількість ВНЗ } \\
\text { у рейтингу }\end{array}$ & $\begin{array}{c}\text { Кількість } \\
\text { показників }\end{array}$ \\
\hline 1 & ARWU & Китай & 2003 & 1200 & 500 & 6 \\
\hline 2 & Webometrics & Іспанія & 2004 & 20000 & 6000 & 4 \\
\hline 3 & $4 \mathrm{ICU}$ & $\begin{array}{l}\text { Світовий інтернет } \\
\text { портал }\end{array}$ & 2005 & 10000 & 200 & 5 \\
\hline 4 & PRSPWU & Тайвань & 2007 & 4000 & 500 & 3 \\
\hline 5 & CWTS & Нідерланди & 2007 & 750 & 100 & 9 \\
\hline 6 & QS & Великобританія & 2009 & 3000 & 200 & 13 \\
\hline 7 & The Times & Великобританія & 2010 & 6000 & 200 & 13 \\
\hline 8 & UI Green Metric & Індонезія & 2010 & 500 & 350 & 41 \\
\hline 9 & URAP & Туреччина & 2010 & 2500 & & 6 \\
\hline 10 & CWUR & Саудівська Аравія & 2012 & 1000 & 100 & 8 \\
\hline 11 & RUR Rankings & Росія & 2013 & 750 & 200 & 20 \\
\hline 12 & GWC & Латвія & 2013 & 1600 & 500 & 3 \\
\hline 13 & U-Multirank & $\begin{array}{l}\text { Німеччина, } \\
\text { Нідерланди }\end{array}$ & 2009 & 1200 & 500 & 31 \\
\hline 14 & $\begin{array}{l}\text { SCImago } \\
\text { Institutions }\end{array}$ & Іспанія & & 3000 & 2900 & 8 \\
\hline
\end{tabular}

ISSN 2312-0967. Фармацевтичний часопис. 2015. № 4 
Агентств з оцінки якості чи будь-яких інших органів державної влади. Як правило, міжнародні рейтинги публікуються у вільному доступі.

Практика використання досвіду світових рейтингів свідчить, що здебільшого інфрормацією для фрормування рейтингу $є$ статистичні дані щодо діяльності ВН3, науково-педагогічного складу, студентів та випускників. Засобами отримання інформації є: анкетування адміністративного, науково-педагогічного складу університетів, студентів, роботодавців; дані веб-сайтів; аналіз публікацій та наукових досліджень; індекси цитування; опитування роботодавців та ін.

Зазначимо, що відмінними рисами світових рейтингів є: методологія їх фрормування, перелік індикаторів та оцінка їх вагомості, методи та засоби ранжування, які за часи існування рейтингів суттєво змінилися. На сучасному етапі також відсутня єдина загальновизнана методологія рейтингування.

Аналіз методологій формування світових рейтингів показав їх відмінність. Так, світові рейтинги університетів світу ARWU, THE в основу своєї методології покладають ранжування ВН3 відповідно з їх академічною та науковою продуктивністю, які досліджуються за різними якісними та кількісними показниками, що характеризують сильні та слабкі сторон як ВНЗ, так і країни в цілому $[10,12,22]$.

Світові університетські рейтинги QS, URAP, PRSPWU, акцентують більшу увагу на оцінці наукової діяльності.

Університетські рейтинги Scimago Institutions і CWTS побудовані на бібліометричних показниках якості досліджень і спрямовані на дослідження наукової продуктивності ВНЗ. Світові рейтинги Webometrics i 4ICU також направлені на дослідження наукової діяльності, але мають свою специфіку, яка полягає у ранжуванні показників на основі даних тільки Web-сторінок ВН3 та наукових сайтів [14, 17].

Світовий рейтинг екологічності ВН3 «UI Green Metric» має власну методологію і кардинально відрізняється від інших рейтингів. Особливість полягає в оцінюванні розвитку ВН3 «зелених» технологій [23].

Різноманітність підходів полягає не тільки у методології формування рейтингів, а в у кількості використовуваних показників. Варіація показників коливається від 4 до 40. Так, наприклад, рейтинги ARWU i Webometrics, URAP оцінюють ВН3 за 4-6 показниками, QS, THE - за 13, тоді як U-Multirank - за 31, а UI Green Metric взагалі за 41 показником.

При цьому проведені дослідження показали, що жоден світовий рейтинг ВНЗ не оцінює якість освіти навчального процесу, а оцінює за показниками, які свідчать про якість освіти.

Посилаючись на дослідження світових рейтингів, визначено різницю у показниках світових рейтингів та їх вагомості. Розподіл показників світових рейтингів за визначеними групами представлено у таблиці 2.

Як видно з наведених даних, деякі світові рейтинги віддають перевагу загальним показникам, інші більш деталізованим. У процесі наукового пошуку було сорормовано основні групи показників ранжування:

- наукова діяльність (частота використання $83 \%)$;

- якість освіти (частота використання - $42 \%$ );

- компетентність викладачів (частота використання - $33 \%$ );

- академічна продуктивність (частота використання $-67 \%)$;

- міжнародна діяльність (частота використання $17 \%)$.

Таблиця 2. Аналіз питомої ваги використовуваних показників світових рейтингів за визначеними групами

\begin{tabular}{|c|c|c|c|c|c|}
\hline \multirow[b]{2}{*}{ Рейтинг } & \multicolumn{5}{|c|}{ Питома вага (\%) та групи використовуваних показників } \\
\hline & $\begin{array}{c}\text { наукова } \\
\text { діяльність }\end{array}$ & $\begin{array}{l}\text { якість } \\
\text { освіти }\end{array}$ & $\begin{array}{c}\text { компетентність } \\
\text { викладачів }\end{array}$ & $\begin{array}{c}\text { академічна } \\
\text { продуктивність }\end{array}$ & $\begin{array}{c}\text { міжнародна } \\
\text { діяльність }\end{array}$ \\
\hline ARWU & 60 & 10 & 20 & 10 & - \\
\hline QS & 60 & 10 & - & 20 & 10 \\
\hline THE & 65 & 15 & 10,5 & 4,5 & 5 \\
\hline PRSPWU & 100 & - & - & - & - \\
\hline RUR & 40 & 40 & - & 20 & - \\
\hline GWC & 30 & - & - & 70 & - \\
\hline CWUR & 25 & 50 & 25 & - & - \\
\hline CWTS & 100 & - & - & - & - \\
\hline SCImago & 100 & - & - & - & - \\
\hline URAP & 100 & - & - & - & - \\
\hline UI Green Metric & - & - & 18 & 82 & - \\
\hline Webo-metrics & - & - & - & 100 & - \\
\hline $4 I C U$ & - & - & - & 100 & - \\
\hline
\end{tabular}

ISSN 2312-0967. Pharmaceutical review. 2015. № 4 
I3 даних таблиці 2 видно, що такі рейтинги, як: PRSPWU, CWTS, SCImago, URAP, Webo-metrics та 4ICU вимірють ВН3 за однією визначеною групою показників. Інші світові рейтинги - ARWU, QS, THE, RUR, GWC, CWUR, UI Green Metric - проводять оцінку ВН3 за декількома визначеними групами. Але немає жодного світового рейтингу, який би оцінював ВН3 за всіма визначеними групами показників.

Таким чином, проведений аналіз питомої ваги показників світових рейтингів показав, що більш розповсюдженим та вагомим є бібліометричні показники, які відображають наукову авторитетність ВН3. Ці показники направлені на зміцнення академічної репутації, підвищення рівня конкурентоспроможності і забезпечення якості освіти у світовому освітньому просторі.

Як видно із даних рисунка 1, рейтинги PRSPWU, CWTS, SCImago, URAP в головному спрямовані на оцінювання наукової діяльності, їх показники більш конкретизовані. Так, рейтинг PRSPWU визначає кількість опублікованих наукових досліджень в друкованих виданнях із списку SCI і SSCl; кількість наукових досліджень в базі даних ESI; індекс авторитетності; кількість статей, опублікованих в найбільш авторитетних наукових друкованих виданнях за останній рік $[14,18,21]$.

Рейтинги CWTS та URAP ранжують ВНЗ за такими показниками, як: середня кількість цитувань у розрахунку на публікацію в даному університеті; середня кількість цитувань публікацій ВН3; частка публікацій університету, що входять в топ 10 найбільш цитованих згідно зі схемою класисрікації Web of Science.

Рейтинг SCImago акцентує увагу на наукометричній базі Scopus - кількість публікацій, індексованих y Scopus; частка публікацій у співавторстві з закордонними організаціями цитування організації щодо середнього у світі значенням; частка журналів, опублікованих у топ 25 представлених у Scopus; частку публікацій організації, що входять в топ 10 найбільш цитованих публікацій; кількість публікацій, у яких автор належить до певного ВН3; частка публікацій, в яких автор певного ВНЗ є першим автором у списку авторів [21].

Світові рейтинги QS, RUR, GWC, CWUR не визначають особливих підходів до вибору показників оцінювання наукової діяльності; ARWU визначає лише кількість публікацій та число цитованих публікацій, опублікованих в журналах Nature або Science; THE звертає увагу на наукова репутацію університету в певних областях; співвідношення захищених дисертацій (Ph.D) до чисельності викладацького складу; співвідношення захищених дисертацій (Ph.D) до кількості бакалаврів; обсяг фрінансування дослідницької

діяльності університету та обсяг фінансування сторонніми компаніями дослідної діяльності університету щодо чисельності профресорсько-викладацького складу та ін. Питома вага цих показників складає від 25 до 60 \% [15, 16, 19, 20]. Рейтинги UI Green Metric, Webo-metrics та 4ICU не оцінюють наукову діяльність взагалі (рис. 2).

Iз рисунка 2 видно, що лише рейтинги ARWU, QS, RUR та CWUR визначають показники ранжування у групі «якість освіти». Так, ARWU вимірює якість освіти через кількість випускників-лауреатів Нобелівської або Медалі Філдса; QS оцінює репутацію ВН3 серед роботодавців; RUR оцінює якість викладання у ВН3; CWUR - кількість випускників ВН3, які одержали основні міжнародні нагороди, медалі, рівень працевлаштування випускників, вимірюваний кількістю випускників ВНЗ, які на сьогодні обіймають посади генерального директора [12, 15, 19, 20].

При аналізі групи «Компетентність викладачів» (рис. 3) встановлено, що тільки чотири із 13 рейтингів оцінюють діяльність викладачів: ARWU - кількість співробітників-лауреатів Нобелівської або Філдсовської премії; ТНЕ - співвідношення опублікованих наукових статей до чисельності професорсько-викладацького складу; UI Green Metric - навчання; CWUR - якість наукововикладацького складу, що вимірюється кількістю співробітників, які одержали головні міжнародні нагороди, призи, медалі [12, 23].

Академічну продуктивність оцінють більше рейтингів, ніж якість освіти чи компетентність викладачів. Так, ARWU розраховує співвідношення усіх показників до загальної чисельності персоналу (10 \%); QS - співвідношення викладацького складу до кількості студентів (20\%); ТНЕ вимірює академічну репутацію університету; ставлення профресорськовикладацького складу до чисельності учнів; середній розмір винагороди представника викладацького складу (21,75 \%); RUR - фрінансову стійкість; навколишнє середовище та інфраструктуру ВН3 (20 \%); UI Green Metric - ефективне використання енергії та вплив на зміни клімату; переробка відходів; раціональне використання водних ресурсів; транспортна політика (82\%) [12, 19, 23]. Рейтинги Webometrics та 4ICU цілком направлені на аналіз академічної продуктивності, а саме на аналіз веб-сторінки сайту ВН3, тому вагомість їх показників в даній групі складає $100 \%$ (рис. 4).

Як вже зазначалося, група показників «міжнародна діяльність» $є$ найменш використовуваною, серед аналізованих рейтингів лише рейтинги QS та THE аналізують міжнародну діяльність ВН3 і оцінюють частку іноземних студентів і викладачів у ВН3 (рис. 5).

ISSN 2312-0967. Фармацевтичний часопис. 2015. № 4 


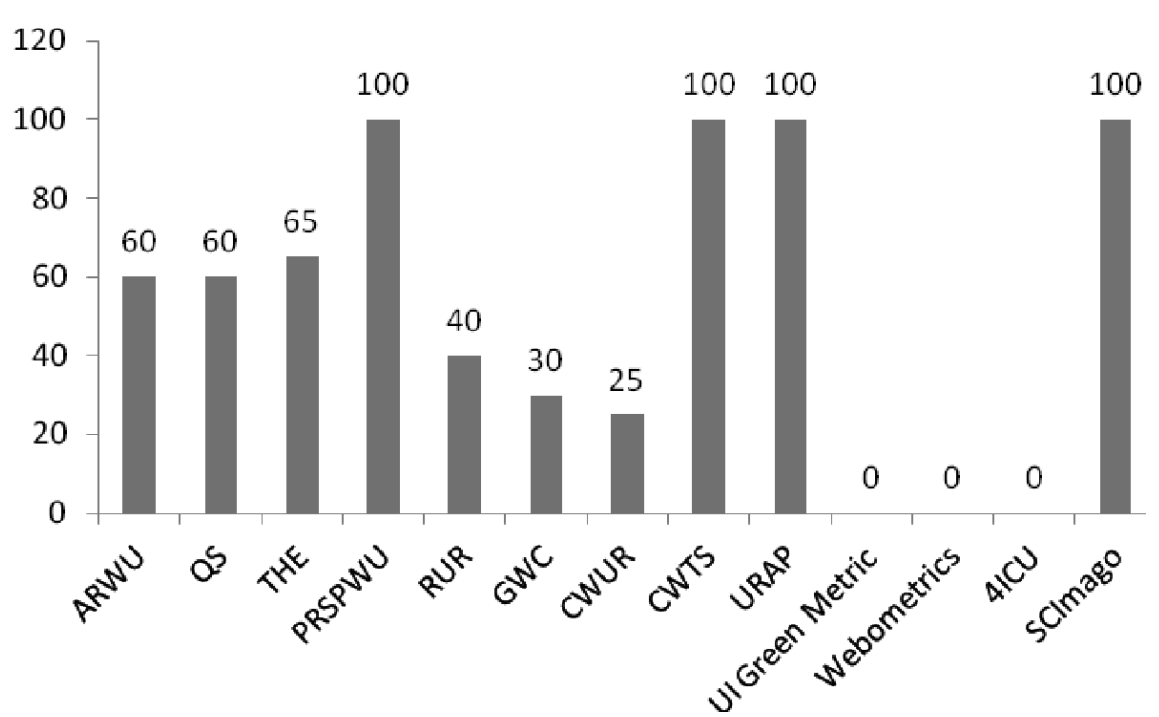

Рис. 1. Аналіз питомої ваги використовуваних показників за групою «Наукова діяльність», (\%).

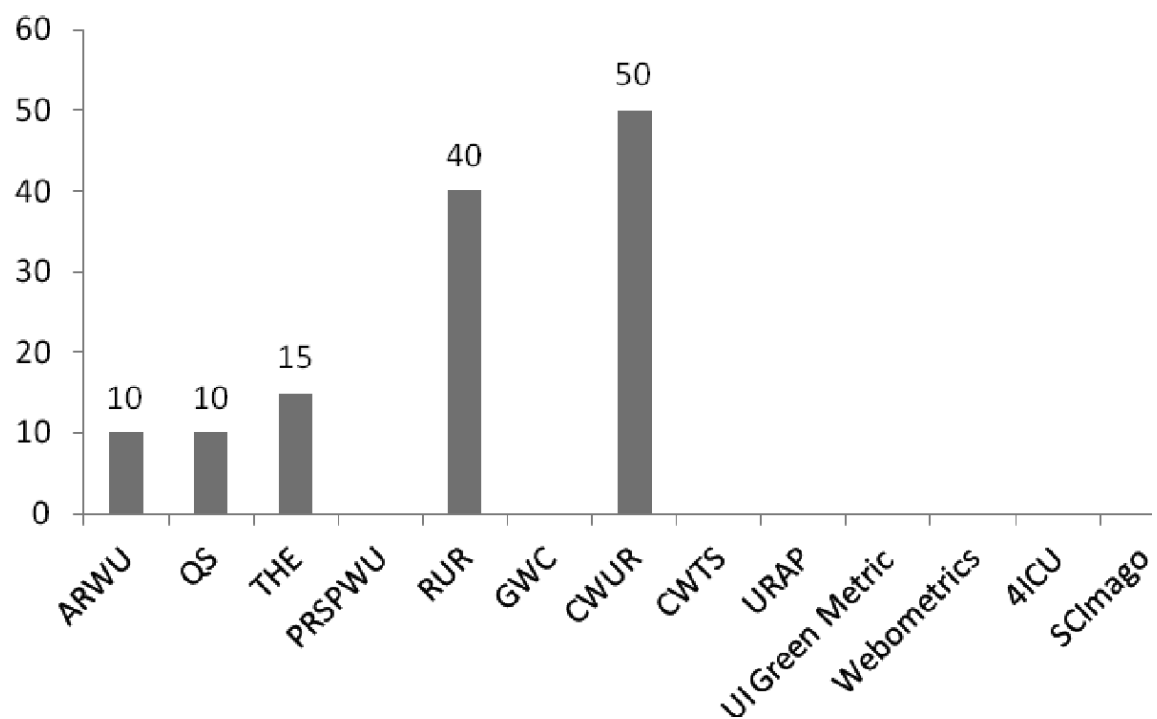

Рис. 2. Аналіз питомої ваги використовуваних показників за групою «якість освіти», (\%).

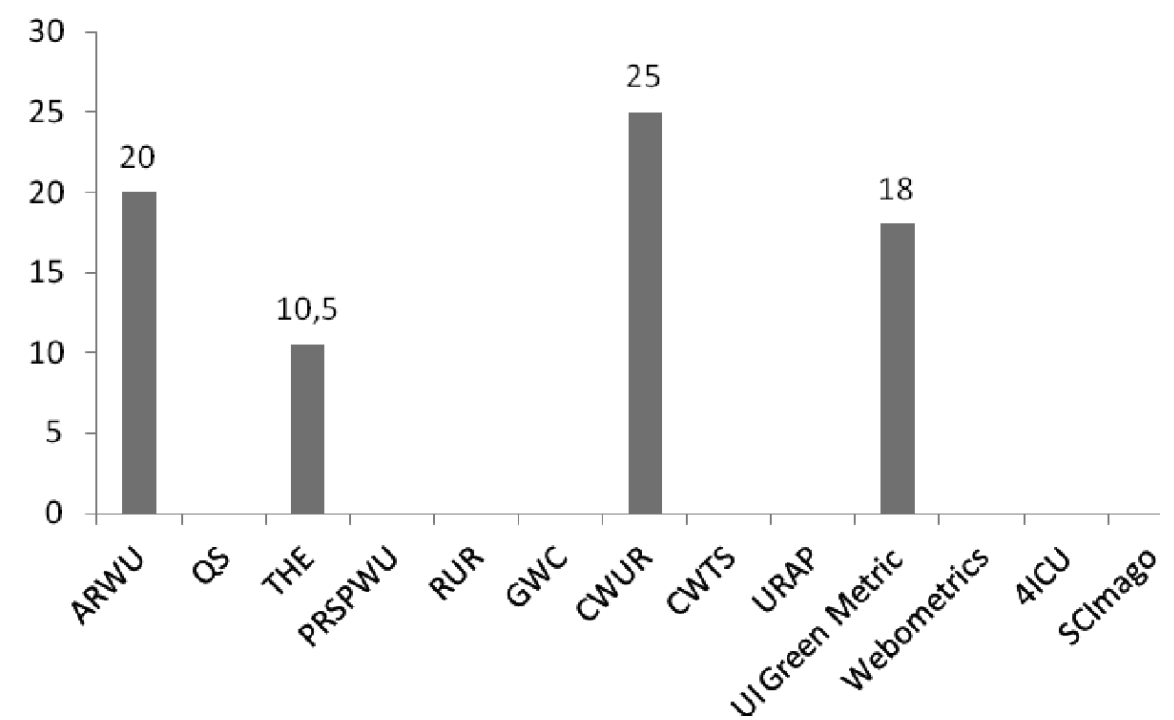

Рис. 3. Аналіз питомої ваги використовуваних показників за групою «Компетентність викладачів», (\%). 
Фармацевтична освіта

Pharmaceutical education

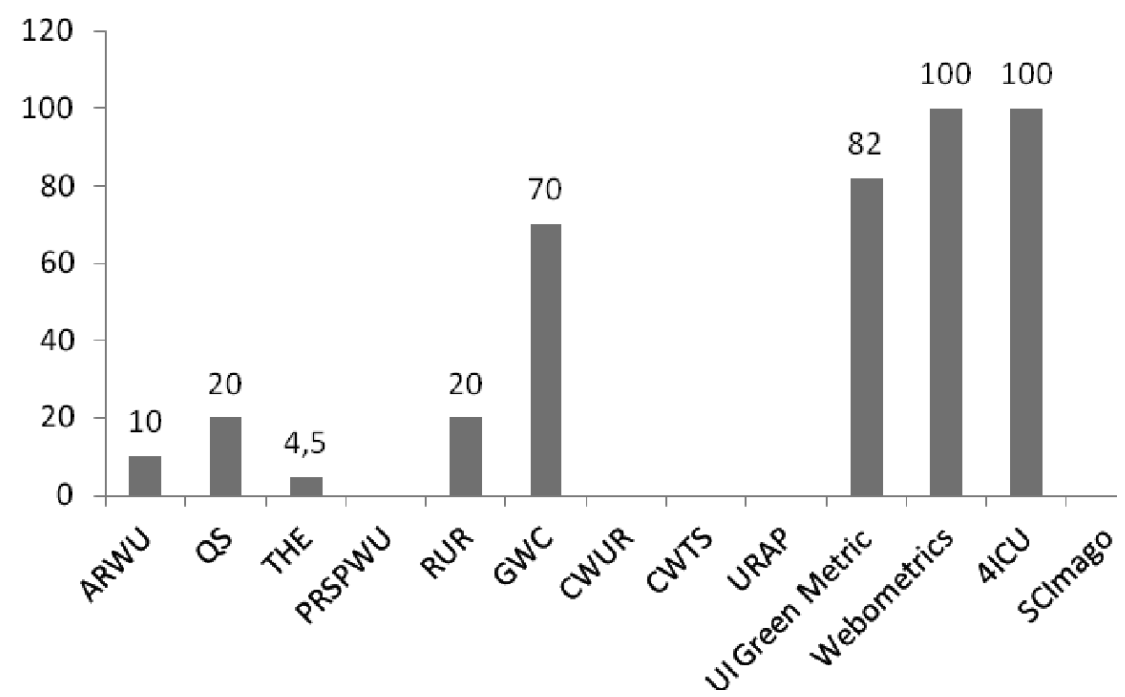

Рис. 4. Аналіз питомої ваги використовуваних показників за групою «Академічна продуктивність», (\%).

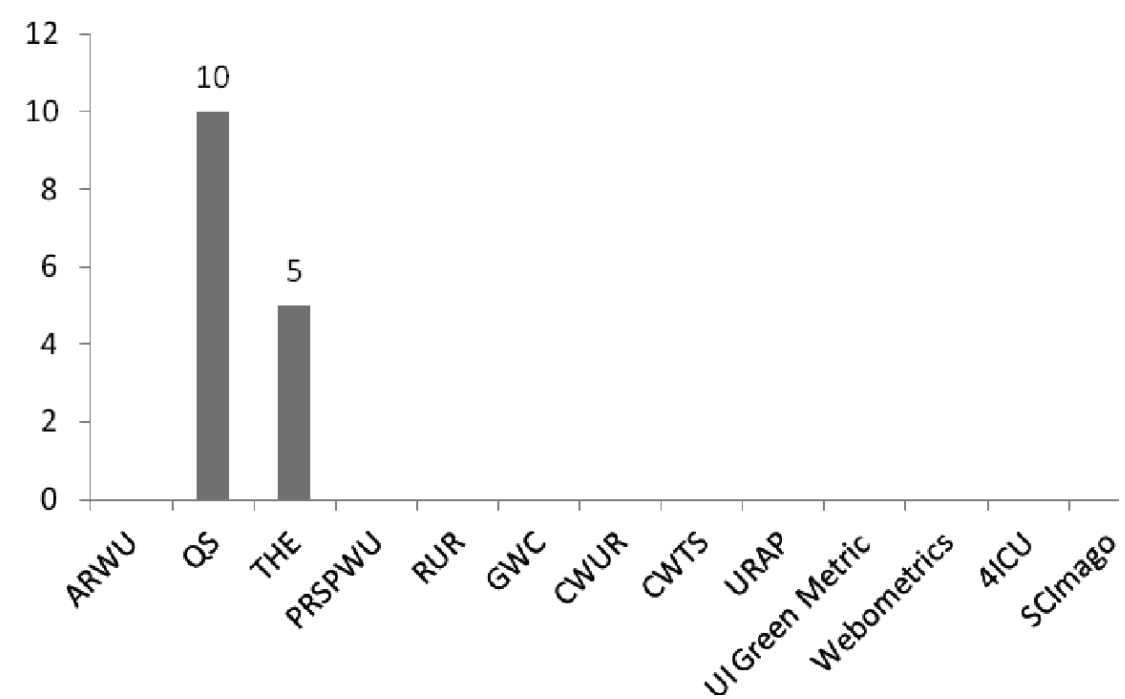

Рис. 5. Аналіз питомої ваги використовуваних показників за групою «Міжнародна діяльність», (\%).

Висновки. Результати досліджень методології та формування світових рейтингів вищих навчальних закладів показали, перш за все, багатоваріантність підходів до оцінки якості освіти, різноманітність критеріїв оцінювання якості освіти, відсутність науково підтверджених обґрунтувань індикаторів ранжування.

Для забезпечення якості на національному рівні та рівні ВН3, у тому числі фрармацевтичного та ме-

\section{Список літератури}

1. Валенкевич Л. П. Аналіз сучасних рейтингів вищих навчальних закладів як інструменту оцінки якості вищої освіти / Л. П. Валенкевич, О.В.Фінкільштейн // Державне регулювання процесів економічного і соціального розвитку. - № 3. (42). - 2013. - С. 36-42.

2. Дубінський О. Г. Міжнародний рейтинг вишів Webometrics: як збільшити значення фрактора переваги // Науковий вісник НЛТУ України. - 2012. - Вип. 22.15 C. 377-384. дичного профрілю, необхідне фрормування певних рейтингів для оцінки діяльності вітчизняних ВН3, що потребує подальшого дослідження методології вітчизняних та національних рейтингів різних країн з урахуванням досвіду світових рейтингів та застосуванням найбільш вагомих показників в побудові системи внутрішнього моніторингу діяльності $\mathrm{BH}$.

3. Згуровський М. Світовий досвід оцінювання університетських рейтингів / [Електронний ресурс] - Режим доступу: www.kampus.com.ua/index.php.

4. Зіменковський Б. С. Рейтинг як складова системи управління якістю підготовки лікарів і провзорів / Б. С. Зіменковський, М. Р. Гжегоцький, І. І. Солонинко // Медична освіта. - 2012. - № 2. - С. 49-51. 5. Ковальов А. В. Оцінка ефективності якості навчальновиховного процесу у ВНЗ / А. В. Ковальов // Теоретичні і

ISSN 2312-0967. Фармацевтичний часопис. 2015. № 4 
практичні аспекти економіки та інтелектуальної власності : збірник наукових праць : у 2-х вип. - Маріуполь, 2013. Вип. 1, Т. 1. - С. 18-21.

6. Колесник Ю. М. Система управління якістю освіти - необхідна складова конкурентоспроможності вітчизняних фрахівців / Ю. М. Колесник, Ю. М. Нерянов, В. М. Компанієць // Вища освіта України.- 2011.- № 3, T. II(27). - C. 240-247.

7. Лесик Р. Б. Роль Інтернет-ресурсів як індикаторних показників у визначенні рейтингів / Р. Б. Лесик, А. Б. Зіменковський, О. І. Лопатинська // Медична та фрармацевтична освіта. -2008. - № 1. - С. 66-70.

8. Михайліченко М. В. Рейтингування як механізм оцінювання якості освітніх послуг / М.В.Михайліченко // Науковий часопис НПУ ім. М. П. Драгоманова. - Випуск 27, 2011. - Серія 5. Педагогічні науки: реалії та перспективи. - С. 180-184. 9. Ранжування діяльності університетів як ключовий інструмент підвищення якості медичної освіти / В. Ф. Москаленко, О. П. Яворовський, Л. І. Остапюк [та ін.] // Медична освіта. - 2012. - № 2. - С. 23-25.

10. Світовий рейтинг университетів (Academic Ranking of World Universities) за 2012 рік [Електронний ресурс]. 2012. - Режим доступу : http://euroosvita.net/index.php/ ?category $=1 \& i d=2102$.

11. Трішкіна Н. І. Система управління якістю - складова європейської освіти // Гуманітариний вісник. Додаток 1 до Вип. 5, Том II (53): Тем. Вип. «Вища освіта України у контекст інтеграції до європейського освітнього простору». К. : Гнозис, 2014. - С. 244-252.

12. Academic Ranking of World Universities: Metodology [Електронний ресурс]. - Режим доступу: http:// www shanghairanking.com

13. Aguillo I. F., Bar-llan J., Levene M., Ortega J. L.(2010): Comparing University Rankings // Scientometrics. Vol. 85. February.

14. CWTS [Електронний ресурс]. - Режим доступу: http:// www.leidenranking.com.

15. CWUR [Електронний ресурс]. - Режим доступу: http:// www.kikstats.com/site/cwur.org

16. Global World Communicator [Електронний ресурс]. Режим доступу: http://www.cicerobook.com.

17. International professional ranking of higher education institutions: [Електронний ресурс]. Режим доступе: http:// www.ensmp.fr.

18. Performance Ranking of Scientific Papers for World Universities : [Электронный ресурс] Режим доступа: http:// ranking.heeact.edu.tw/en-us.

19. QS [Електронний ресурс]. - Режим доступу: http://www. topuniversities.com/qs-world-university-rankings.

20. RUR [Електронний ресурс]. - Режим доступу: http:// www.roundranking.com.

21. SCImago Institutions Rankings: [Електронний ресурс]. Режим доступу: http://www.scimagoir.com.

22. Times Higher Education [Електронний ресурс]. - Режим доступу: http://www.timeshighereducation.co.uk.

23. UI Green Metric Ranking of World Universities [Електронний ресурс]. - Режим доступу: http:// www.greenmetric. ui.ac.id.

24. U-Multirank: [Електронний ресурс]. - Режим доступу: http://www.umultirank.org.

25. Webometrics Ranking of World Universities: [Електронний ресурс]. - Режим доступу: http://www.webometrics.info.

\title{
ТЕОРЕТИКО-МЕТОДОЛОГИЧЕСКИЕ ПОДХОДЫ К ОЦЕНКЕ КАЧЕСТВА ВЫСШЕГО ОБРАЗОВАНИЯ В КОНТЕКСТЕ МИРОВЫХ РЕЙТИНГОВ ВЫСШИХ УЧЕБНЫХ ЗАВЕДЕНИЙ
}

\author{
А. В. Кайдалова, А. В. Посылкина \\ Национальный фрармацевтический университет, Харьков
}

Резюме: в статье рассмотрены мировые рейтинги высшихучебных заведений; принципы и методология построения рейтингов, их основные индикаторы, показатели ранжирования высших учебных заведений и их роль в оценке качества образования.

Ключевые слова: качество образования, мировые рейтинги высших учебных заведений, индикаторные показатели в определении рейтингов, критерии оценивания уровня качества.

\section{THEORETICAL AND METHODOLOGICAL APPROACHES TO THE EVALUATION OF THE QUALITY OF HIGHER EDUCATION WITHIN THE CONTEXT OF THE WORLD HIGHER EDUCATION INSTITUTIONS RATINGS}

\section{A. V. Kaydalova, O. V. Posylkina \\ National Pharmaceutical University, Kharkiv}

Summary: in the article we have reviewed the world rankings of the higher education institutions; principles and methodology of ratings, their key indicators, the indices of ranking the higher education institutions and their role in assessing the quality of education.

Key words: quality of education, world rankings of the higher education institutions, indicating indices in determining ratings, criteria for evaluation of the quality level. 